\title{
Comparative Studies of the Use of Management Accounting Information
}

\author{
Ewelina Zarzycka \\ University of Lodz | ezarzycka@uni.lodz.pl
}

\section{Justyna Dobroszek}

University of Lodz | jdobroszek@uni.lodz.pl

\section{Alina Almasan}

West University of Timisoara | alina.almasan@e-uvt.ro

\section{Cristina Circa}

West University of Timisoara | cristina.circa@e-uvt.ro

Volume 7 No 2 (2017) ｜ＩSSN 2158-8708 (online) ｜ＤOI 10.5195/emaj.2017.143 | http://emaj.pitt.edu |

\begin{abstract}
The paper uses the phenomenon of isomorphism to present the similarities and differences in the use of management accounting information by managers in Poland and Romania. In order to analyze the set of data obtained from the conducted survey, cluster analysis and descriptive statistics have been applied. The studied managers use mainly management accounting information for planning and control tasks (budgeting) and less for formulating strategy and decision making. In their work, they rather apply financial data than nonfinancial indicators. The findings confirm that management accounting in both countries is strongly influenced by the mechanisms of coercive, normative and mimetic isomorphism connected with their specific economic and political development.
\end{abstract}

Keywords: Management Accounting, Information, Managers, Comparative Studies

\section{$(\mathrm{cc})$ EY}

New articles in this journal are licensed under a Creative Commons Attribution 3.0 United States License.

\section{UILIS D-Sunt}

This journal is published by the University Library System of the University of Pittsburgh as part of its D-Scribe Digital Publishing Program, and is cosponsored by the University of Pittsburgh Press. 


\section{Comparative Studies of the Use of Management Accounting Information}

\author{
Ewelina Zarzycka \\ Justyna Dobroszek \\ Alina Almasan \\ Cristina Circa
}

\section{Introduction}

The importance of comparative management accounting studies is undisputable, as they are especially relevant for corporate practices. Particularly multinational corporations consider that country-specific conditions influence the effectiveness of management accounting practices in subsidiaries operating in different national settings. In this context, comparative studies help companies to identify and understand the inefficiencies of management accounting systems in country specific cases (see Endenich et al., 2011). Comparative studies of management accounting focus on management accounting practices from different countries or cultural regions (see Shields et al., 1991; Ahrens, 1996; Chow et al., 1996), either matching companies from two or more countries, or checking practices identified in one country against literature. Most comparative researches deal with Japanese (see Shields et al., 1991; Chow et al., 1996) and Western European management accounting techniques (see Wagenhofer, 2006). The comparisons with the Anglo-American world as well as the great interest in German management accounting are dominant.

Comparative studies of management accounting practices in Central and Eastern Europe (CEE) are rare. This is due to the fact that management accounting was brought into use in enterprises operating in CEE after the fall of communism. From 1945 to 1989, given the planned economy and the centralized management system, management accounting was employed in CEE countries only to an extremely low extent, limited to the use of some elements of cost accounting. With the change of the political system, the centrally planned economy was abandoned and foreign investments were attracted to this region, leading to a rapid development of management accounting, both in practice and in research. Tools and methods were implemented first in companies with foreign capital, who brought solutions used by headquarters and parent companies (see Grosu et al., 2014; Albu and Albu, 2012; Szychta, 2002).

In this context, the aim of the paper is to find answers to important questions regarding the use of management accounting information by managers from Poland and Romania:

- to what extent the information provided by management accounting systems is used for performing management tasks

- how useful is the selected information provided by the management accounting system for the management process.
Worldwide, the number of comparative studies of management accounting is significant; yet, there are no studies of the use of management accounting information by managers. The increasing number of calls for papers on the topic of management accounting in transitional and emerging economies indicates the growing academic interest in these regions (Endenich et al., 2011). Our paper contributes to a better understanding of the management accounting design and use in foreign subsidiaries and companies operating in former communist CEE countries. The direct comparison between Poland and Romania is focused on the application and transferability of management accounting practices, with a special attention paid to the usefulness of management accounting information for managerial tasks. As a result, the findings of the study are beneficial for both the theory of management accounting and the practices of companies operating in the Central and Eastern Europe.

Our study employs the institutional theory, mainly the concept of isomorphism, in order to explain the similar use of management accounting by managers from the two countries. The institutional theory is expected to generate interesting results, especially in the area of comparative studies, as it helps to explore the influences of global trends and professionalization on the use and design of management control systems in developing countries. Combining institutional theory and comparative studies can be also helpful for understanding country-specific styles and aims of management accounting information, as well as links between incentive structures and different institutional conditions (see Endenich et al., 2011). According to the institutional theory, companies transfer institutionalized management accounting practices accepted by other companies or in other countries (see Meyer and Scott, 1992). Management accounting is introduced and used as a consequence of coercive, mimetic and normative pressures (see DiMaggio and Powell, 1983).

Our study reveals many similarities in the use of management accounting information by managers from Poland and Romania. Both in Poland and in Romania, managers use management accounting information for control and decisionmaking purposes, as well as for strategy implementation, while mainly financial data are employed in the management process. However, the study identifies some differences in the evaluation of management information by managers. The paper is divided into four sections. Section one is the introduction. Section two outlines the theoretical framework of institutional theory and isomorphism. The third section discusses the research methodology, presents the research sample and reports the findings of the cluster analysis. The final and fourth section consists of conclusions.

\section{Isomorphism as a theoretical framework for} understanding similarities and differences

The concept of institutional isomorphism, developed by DiMaggio and Powell (1983) is extremely useful for understanding the homogeneity and similarities of organizations. The authors, investigating the organizational uniformity of contemporary organizations, concluded that the isomorphism is a source of institutional change. The creation and structuring of an organizational field, defined as an institutionally separated system of relations between specific organizations, is subject to three isomorphic mechanisms: coercive, mimetic and normative. The first type of isomorphism results from political influences and concerns the problem of legitimacy. The second one has its source in typical reactions to 
uncertainty, whereas the third one is related to the processes of professionalization. Isomorphism can be formal or informal, as isomorphic pressure may come from direct collaborators, from other institutions on which the organization depends, from the legal context within which the organization operates and finally from the public.

The concept of isomorphism was used by Granlund and Lukka (1998) to investigate the cause of the global homogenization of management accounting practices. The authors identified that coercive isomorphism resulting in the homogeneity of management accounting practices is reflected in international legislation (e.g.: EU directives), international trade agreements (e.g.: WTO, NAFTA), in the harmonization of financial accounting and reporting rules as well as in the corporate influence of multinationals on local subsidiaries. Professionalization and university education in business and management represent the normative isomorphism, which is, according to authors, another factor contributing to the similarities in management accounting practices. The last group of homogenization factors is related to the mechanism of mimetic isomorphism. The authors highlighted the influence of global advisory firms and the practice of copying competitors' practices by companies on the homogeneity of management accounting (see Granlund and Lukka 1998, p. 157). Also Granlund (2001), explaining the consistency of management accounting practices drew attention to the effect of mimetic (copying management accounting methods and consultant opinion) and normative isomorphism (conservative organizational culture, accountants' conservatism).

\section{Empirical research of the use of management accounting information}

\subsection{Aim of the paper and research methodology}

In Romania and Poland, management accounting has been practiced and taught in universities for a relatively short period of time, due to the fact that the market economy was introduced to this region only in the 1990s. It was then that local companies discovered the need to take advantage of management accounting. Yet, as regards foreign companies operating in CEE through affiliates and branches, strategic decisions are taken by the head office. Hence, at local level, there is no need to use a wide range of management accounting tools that would support, among others, those decisions (see Grosu et al., 2014; Albu and Albu, 2012; Szychta, 2002). Therefore, the purpose of the study is to compare the use of management accounting information by managers in Poland and Romania. We aim at answering the following questions:

- $\quad$ to what extent do the surveyed managers use management accounting information for the performance of the indicated management tasks;

- how useful is the selected information provided by the management accounting system for the management process.

The paper relies on an empirical research, performed by the authors from May 2015 to March 2016, on randomly selected companies operating in Poland and Romania. Firstly, the questionnaire-based survey was pretested in both countries. Then, the sample of 1000 enterprises was selected from the available databases of Tax Identification Numbers of companies in each country. The questionnaire-based survey employed in our research was sent online to managers of selected companies. 154 companies completed the questionnaire correctly (response rate: 15.4\%). Out of 154 responses, 116 originated from Poland and 38 from Romania. The survey was conducted in the national language of the respondents. The questionnaire was structured in four different sections: the first two outlined a brief characterization of the company, respectively of the respondent, the third section was focused on the organization of the management accounting system within the companies, while the fourth section included questions meant to capture the managers' assessment of the use of management accounting information.

In order to thoroughly analyze the data obtained from the conducted survey, cluster analysis has been applied. This method allows for segregating the observed data into specific groups, so that the association degree of certain objects with other objects belonging to the same group is as high as possible, and with objects from other groups - as low as possible. This tool systematizes the gathered information to a large extent into specific structures and, consequently, gives an overview of the surveyed objects.

First, the variables were classified by means of the agglomerative (hierarchical) method, in which the Euclidean distance was applied in order to calculate the distance between objects, and of Ward's method. This way, the variables were divided into pairs or larger groups (agglomerations, clusters) most similar to each other. In the next stage, the data were grouped according to objects (respondents) using the k-means method that allows for imposing the number of created clusters. It was assumed that the respondents will be divided into 3 groups.

\subsection{Research sample}

The companies from Poland and Romania involved in the study were mainly manufacturing enterprises (52\%, respectively $61 \%$ ). About $30 \%$ of the companies from both countries were service providers, while slightly over $10 \%$ were trade companies. Over $60 \%$ of the surveyed companies could be classified as large in terms of their number of employees. Most companies from Poland and Romania had foreign capital: 42\%, respectively $57 \%$ of the study population.

The educational level of the surveyed managers should be pointed out. 98\% of the Polish managers hold a Master's degree, $40 \%$ have completed an MBA and $9 \%$ hold a $\mathrm{PhD}$, while $68 \%$ of the Romanian managers hold a Master's degree with only $13 \%$ having an MBA degree.

\subsection{The assessed use of management accounting information - cluster analysis results}

The use of the agglomerative method showed an interesting overview of the extent to which managers use the information provided by management accounting for the performance of management tasks. In both countries, the agglomerative method showed three clusters at the lowest level of the agglomeration: planning and budgeting and cost and financial control (cluster 1), performance measurement (cluster 2), formulation and implementation of strategy and decision making (cluster 3) in Poland, respectively planning and budgeting and performance measurement (cluster 1), cost and financial control (cluster 2), strategy formulation and implementation and decision making (cluster 3) in Romania. 


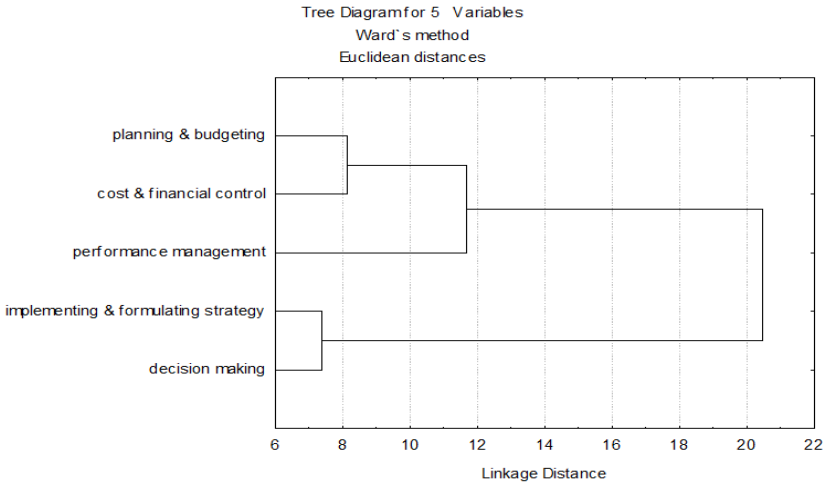

Fig. 1. The use of the information provided by the management accounting system for the performance of management activities in Poland.

Source: Authors' own processing

At the higher agglomerative level, both investigated countries showed the same two main clusters. The first one consists of traditional tasks of management accounting (related to control), i.e. planning and budgeting, cost and financial control, and performance measurement. The second one includes tasks related to decision making and strategy formulation and implementation (related to decision-making) (see figures 1 and 2).

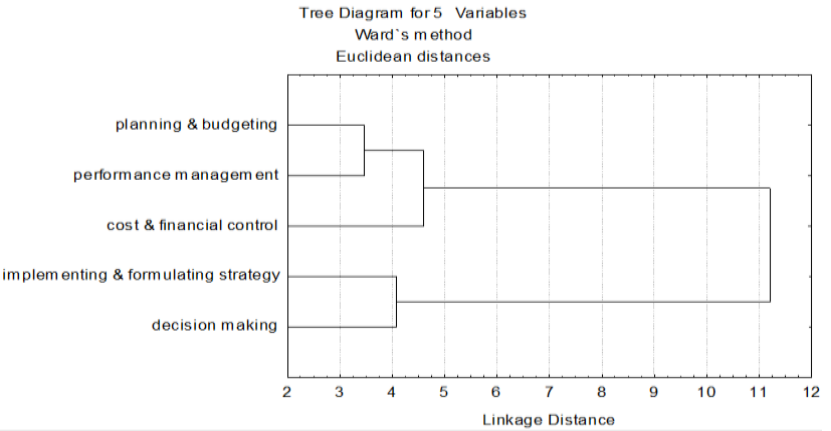

Fig. 2. The use of the information provided by the management accounting system for the performance of management activities in Romania

Source: Authors' own processing

The figures above confirm that both in Poland, and in Romania, the respondents' assessments as regards the use of management accounting information for control tasks and decision-making purposes are close to each other. This state of affairs may indicate that the respondents explicitly direct the use of management accounting information to the first or the second group of tasks, i.e. tasks related to control or to decision-making and strategy implementation.

In conclusion, the respondents' answers to the analyzed questions can be divided into three homogeneous structures of tasks, i.e. homogeneous within a cluster but significantly different between groups. Considering the higher level of aggregation, we can introduce a division into two homogeneous groups, i.e. group 1 for control activities and group 2 for decision making. In the latter case, this may suggest a division of the managers into two homogeneous groups, i.e. those using information for control related activities (group 1) and those using management accounting information for decision making (group 2). Both within group 1 and within group 2, the assessments of the respondents regarding the association of the information with a specific type of tasks were similar. This means that if respondents assessed e.g. the extent to which the information is used for budgeting tasks as very high, they usually assessed the suitability of this information for cost and financial control in a similar manner. The above conclusions are complemented with the result of grouping the objects (respondents) with the $\mathrm{k}$-means method (where $\mathrm{k}=3$ ), as shown in figures 3 and 4.

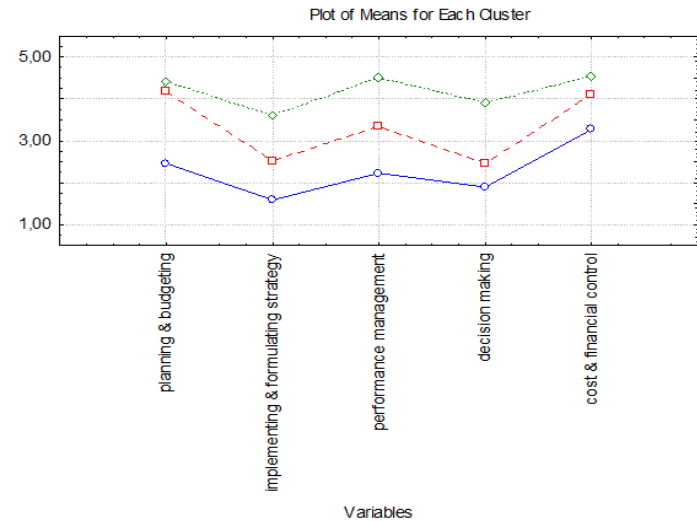

- - Cluster 1
- - Cluster 2
- .. Cluster 3

Fig. 3. The results of object (respondent) grouping with the k-means method as regards the use of management accounting information for indicated management tasks by managers in Poland.

Source: Authors' own processing

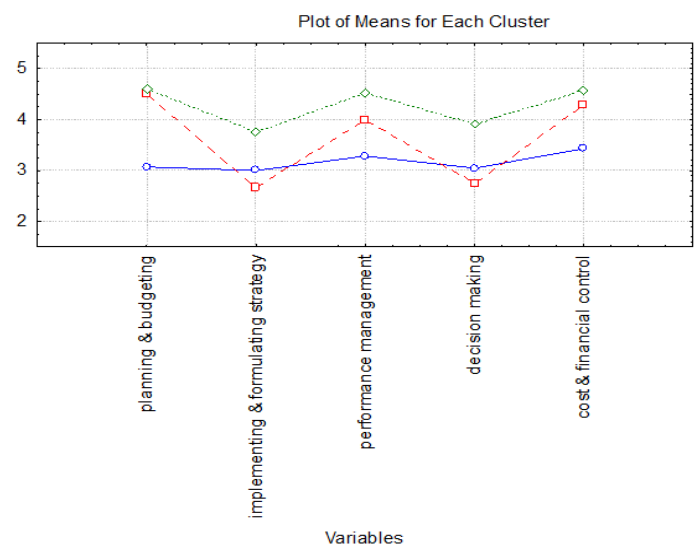

- Cluster 1 Variables - - Cluster 2

Fig. 4. The results of object (respondent) grouping with the k-means method as regards the use of management accounting information for indicated management tasks by managers in Romania

Source: Authors' own processing

In the classification of the managers in Poland into three clusters, there is a clear arrangement of the respondents who rated the suitability of management accounting information for the performance of the indicated activities as poor, moderate, and high. They can be divided into the socalled sceptics, neutral, and supporters. Also, it should be stressed that the three clusters differ in terms of the average assessments of all the tools. As a rule, respondents belonging to the group who assessed the suitability of information for control purposes as higher than the respondents from the second and third group, also judged the suitability of the information for decision making and strategy implementation tasks as high.

As for Romania, it should be stressed that the three clusters differ in terms of average assessments. As a rule, respondents belonging to the group who rated the suitability of information for control purposes described above (cluster 3) higher than the second group (cluster 2), also judged the 
suitability of information from the scope of decision making and implementation of strategy as high. The only exception is the use of the information for planning and budgeting, since it was assessed similarly by the respondents from group 2 and 3. The third group (cluster 1) made a similar and relatively poor average assessment of the use of the information for each of the examined areas.

Tables 1 and 2 provide information on the differences in the average assessments of these three groups, visible on the attached figures. It is worth noting that the sizes of individual clusters in Poland are rather similar (26, 32, and 34), although the cluster of the persons rating the suitability of information as high is relatively the largest.

Table 1: The use of management accounting system information for the performance of the indicated activities manager clusters in Poland

\begin{tabular}{c|c|c|c} 
Managerial activities & Mean & Standard - Deviation & Variance \\
\hline \multicolumn{2}{c}{ Cluster 1 (lower average use) contains 26 cases } \\
\hline Planning \& budgeting & 2.461 & 0.882 & 0.778 \\
\hline Formulating \& implementing strategy & 1.589 & 0.583 & 0.340 \\
\hline Performance management & 2.231 & 0.764 & 0.584 \\
\hline Decision making & 1.897 & 0.658 & 0.433 \\
\hline Cost \& financial control & 3.269 & 0.992 & 0.984 \\
\hline \multicolumn{2}{c}{ Cluster 2 (moderate average use) contains 32 cases } \\
\hline Planning \& budgeting & 4.187 & 0.564 & 0.318 \\
\hline Formulating \& implementing strategy & 2.520 & 0.633 & 0.400 \\
\hline Performance management & 3.343 & 0.945 & 0.894 \\
\hline Decision making & 2.458 & 0.560 & 0.313 \\
\hline Cost \& financial control & 4.125 & 0.635 & 0.403 \\
\hline Cluster 3 (higher average use) contains 34 cases \\
\hline Planning \& budgeting & 4.411 & 0.608 & 0.370 \\
\hline Formulating \& implementing strategy & 3.627 & 0.723 & 0.523 \\
\hline Performance management & 4.500 & 0.550 & 0.303 \\
\hline Decision making & 3.901 & 0.694 & 0.481 \\
\hline Cost \& financial control & 4.529 & 0.407 & 0.165
\end{tabular}

Source: Authors' own processing

In Romania, we notice that the cluster who evaluated the suitability of information higher is the largest.

Table 2: The use of management accounting system information for the performance of the indicated activities manager clusters in Romania

\begin{tabular}{c|c|c|c} 
Managerial activities & Mean & Standard - Deviation & Variance \\
\hline \multicolumn{2}{c}{ Cluster 1 (lower average use) contains 7 cases } \\
\hline Planning \& budgeting & 3.071 & 0.449 & 0.202 \\
\hline Formulating \& implementing strategy & 3.000 & 0.793 & 0.629 \\
\hline Performance management & 3.285 & 0.698 & 0.488 \\
\hline Decision making & 3.047 & 0.705 & 0.497 \\
\hline Cost \& financial control & 3.428 & 0.731 & 0.535 \\
\hline \multicolumn{4}{c}{ Cluster 2 (moderate average use contains 11 cases } \\
\hline Planning \& budgeting & 4.500 & 0.447 & 0.200 \\
\hline Formulating \& implementing strategy & 2.666 & 0.596 & 0.355 \\
\hline Performance management & 4.000 & 0.547 & 0.300 \\
\hline Decision making & 2.757 & 0.634 & 0.402 \\
\hline Cost \& financial control & 4.272 & 0.606 & 0.368 \\
\hline Cluster 3 (higher average use) contains 16 cases \\
\hline Planning \& budgeting & 4.593 & 0.327 & 0.107 \\
\hline Formulating \& implementing strategy & 3.750 & 0.479 & 0.229 \\
\hline Performance management & 4.531 & 0.385 & 0.148 \\
\hline Decision making & 3.916 & 0.463 & 0.214 \\
\hline Cost \& financial control & 4.562 & 0.573 & 0.329
\end{tabular}

Source: Authors' own processing

In conclusion, the cluster analysis indicated a clear scope of the tasks for which management accounting information is used by the surveyed managers in Poland. As part of this analysis, the agglomerative method enabled the detection of manager clusters who use the information for control and for decision-making purposes. In addition, the use of the k-means method for the analyzed data lead to the identification of three clusters of managers, the so-called sceptics, neutral, and supporters of management accounting information.

\subsection{The assessed usefulness of management accounting information - cluster analysis results}

The agglomerative method has also been used for the cluster analysis regarding the assessed suitability of selected management accounting information for management processes. Following variables have been taken into account: financial information (financial result, costs and revenues), budgetary data, variance analysis and non-financial indicators. After the first stage of clustering, two main clusters were generated in both countries. In Poland, the first cluster consists of financial information and budgetary data, while the second one includes non-financial indicators, as illustrated by figure 5 .

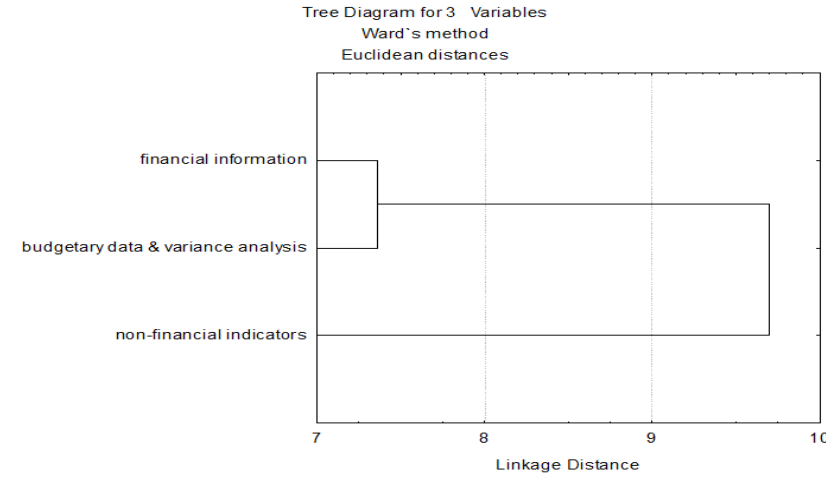

Fig. 5. The assessed suitability of selected management accounting information in Poland

Source: Authors' own processing

This division shows clearly that, the respondents' answers regarding the assessed suitability of financial information and budgetary data \& variance analysis are close. More, the assessments of specific types of management accounting information can be divided into two homogeneous groups of information, which may affect the division of the two groups of managers, i.e. those applying financial information and budgetary data (group 1) and those using the non-financial indicators (group 2). The suitability assessments of financial and budgetary data were similar. For example, if respondents evaluated the suitability of financial information as high, they generally also evaluated the suitability of budgetary and variance information as high.

Slightly different than in the case of Poland, in Romania the first cluster includes financial information, and the second one consists of budgetary data \& variance analysis, as well as non-financial indicators. 


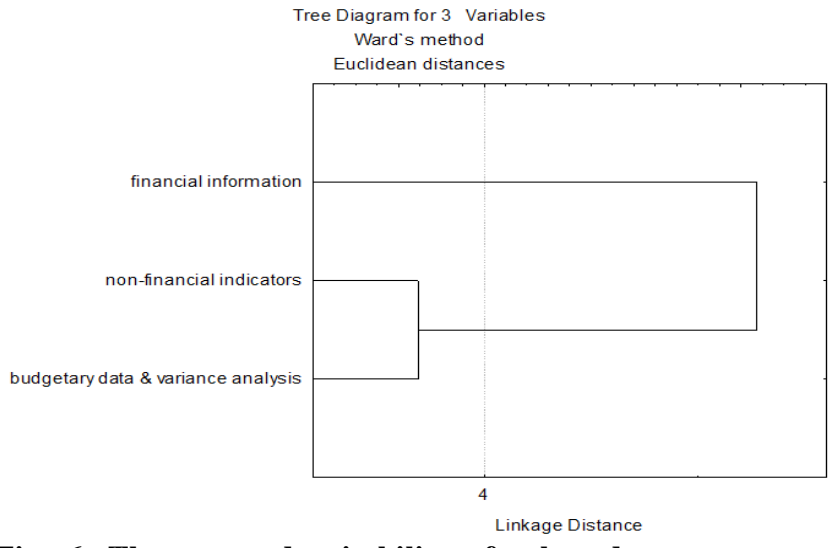

Fig. 6. The assessed suitability of selected management accounting information in Romania

Source: Authors' own processing

The respondents' answers regarding the assessed suitability of budgetary data \& variance analysis and indicators are close. The assessments of specific types of management accounting information can be divided into two homogeneous groups, pointing to two homogeneous manager groups: those applying financial information (group 1) and those applying the indicators and budgetary data \& variance analysis (group 2). The suitability assessments of financial and budgetary information were similar, too.

For both countries, the above results are complemented by the result of object (respondent) grouping with the $\mathrm{k}$-means method (where $\mathrm{k}=3$ ), as shown in figures 7 and 8.

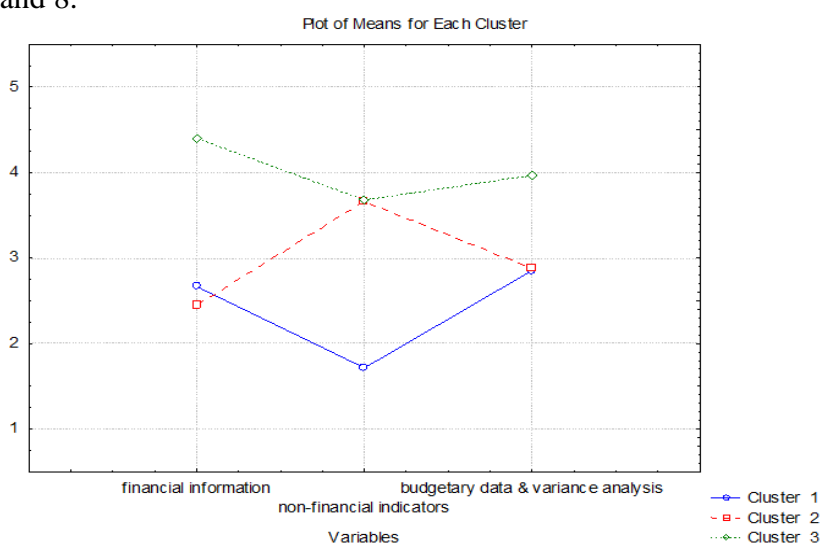

Fig. 7. Object (respondent) grouping with the k-means method in respect of the assessed suitability of selected management accounting information in Poland

Source: Authors' own processing

In the classification into three clusters from Poland, we observe a clear division between respondents who evaluated the suitability of selected management accounting information as poor (cluster 1) and as high (cluster 3), establishing a border between sceptics and supporters. It should be noted that these two clusters differ in terms of the average assessments of all information. The third separated group (cluster 2) is placed between the two groups discussed above and assesses the suitability of the indicators as high, similar to cluster 3, respectively the suitability of financial and budgetary information as poor, similar to cluster 1 .

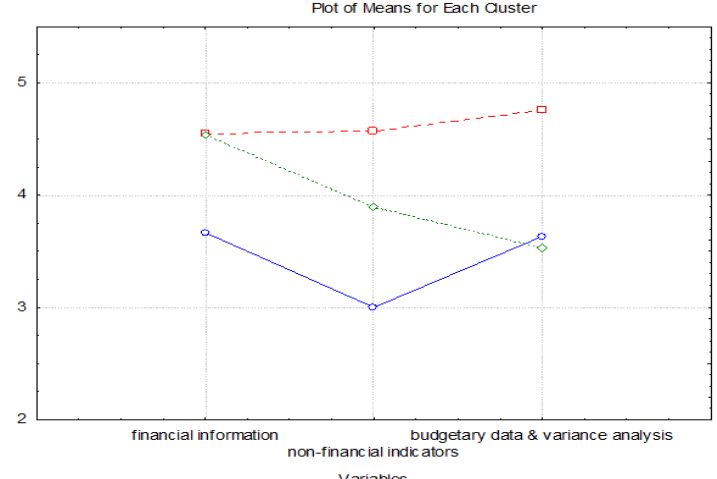

variables

Fig. 8. Object (respondent) grouping with the k-means method in respect of the assessed suitability of selected management accounting information in Romania

Source: Authors' own processing.

In the case of Romania, the division into 3 clusters indicates three groups of managers who rated management accounting information as a support of management tasks as poor (cluster 1), high (cluster 2), and moderate (cluster 3). Hence we can define three manager groups: sceptics, supporters, and neutral. The three indicated clusters differ in terms of average assessments. As a rule, the managers from the group who evaluated the suitability of financial information as high also rated budgets and indicators as high, contrary to managers from the other group. The exception is financial information, which was judged as high by both manager groups. Furthermore, budgetary data \& variance were rated slightly higher by the group of managers called sceptics than by the group created by the so-called "neutral" managers. Tables 3 and 4 present information on the differences in the average answers of the three groups for each of the two countries. In both countries, the largest cluster is the one of the supporters (cf. table 3 and 4).

Table 3: The assessed suitability of selected management accounting information in Poland

\begin{tabular}{c|c|c|c}
\hline Type of information & Mean & Standard - Deviation & Variance \\
\hline \multicolumn{4}{c}{ Cluster 1 (lower average assessment) contains 14 cases } \\
\hline Financial information & 2.666 & 0.942 & 0.888 \\
\hline Non-financial indicators & 1.714 & 0.544 & 0.296 \\
\hline Budgetary data \& variance analysis & 2.857 & 0.844 & 0.713 \\
\hline \multicolumn{4}{c}{ Cluster 2 (moderate average assessment) contains 6 cases } \\
\hline Financial information & 2.444 & 0.688 & 0.474 \\
\hline Non-financial indicators & 3.666 & 0.683 & 0.466 \\
\hline Budgetary data \& variance analysis & 2.888 & 0.455 & 0.207 \\
\hline \multicolumn{4}{c}{ Cluster 3 (higher average assessment) contains 6 cases } \\
\hline Financial information & 4.398 & 0.432 & 0.186 \\
\hline Non-financial indicators & 3.680 & 0.618 & 0.382 \\
\hline Budgetary data \& variance analysis & 3.972 & 0.508 & 0.258 \\
\hline
\end{tabular}

Source: Authors' own processing

Table 4: The assessed suitability of selected management accounting information in Romania

\begin{tabular}{c|c|c|c|}
\hline Type of information & Mean & Standard - Deviation & Variance \\
\hline Cluster 1 (lower average assessment) contains 10 cases \\
\hline Financial information & 3.666 & 0.496 & 0.246 \\
\hline Non-financial indicators & 3.000 & 0.577 & 0.333 \\
\hline Budgetary data \& variance analysis & 3.633 & 0.531 & 0.282 \\
\hline \multicolumn{4}{c}{ Cluster 2 (higher average assessment) contains 14 cases } \\
\hline Financial information & 4.547 & 0.464 & 0.215 \\
\hline Non-financial indicators & 4.571 & 0.385 & 0.148 \\
\hline Budgetary data \& variance analysis & 4.761 & 0.304 & 0.092 \\
\hline \multicolumn{4}{c}{ Cluster 3 (moderate average assessment) contains 10 cases } \\
\hline Financial information & 4.533 & 0.391 & 0.153 \\
\hline Non-financial indicators & 3.900 & 0.316 & 0.100 \\
\hline Budgetary data \& variance analysis & 3.533 & 0.525 & 0.276 \\
\hline
\end{tabular}

Source: Authors' own processing 


\section{Conclusions}

The results of the cluster analysis showed that management accounting information is employed in a similar manner in the two countries included in the study. Both in Poland and in Romania, the agglomerative method enabled the detection of very similar clusters of responses within the examined scope. Therefore, it is possible to isolate managers who use management accounting information rather for control purposes and managers who use the respective information for decision-making and strategy implementation. In both countries, we managed to separate groups with similar assessments of management accounting information, in terms of its use and usefulness, whereas the high rating cluster was larger than the other groups.

We found minor differences between the two countries included in the study, regarding the assessed usefulness of management accounting information, i.e. the types of clusters were different, at the higher level of agglomeration. In Poland, the first cluster consisted of financial information and budgetary data, while the second one - of nonfinancial indicators, while in Romania, the first cluster included solely financial information, and the second one budgetary data \& variance analysis, as well as non-financial indicators. As a result, it can be concluded that managers focus in both countries rather on financial data. In the case of the managers in Poland, budgetary data \& variance analysis belonged to the same group as financial information, and were used both for the support of tasks associated with planning as well as for control tasks. In Romania, budgetary data \& variance analysis belonged to the same group as the indicators.

The high similarity in the use of management accounting information by managers can be explained by the isomorphism and the economic situation in both countries. Management accounting systems in companies operating in Poland and Romania are strongly influenced by the mechanisms of isomorphism, both coercive, normative, and mimetic, which lead to system homogeneity. Coercive pressure is translated in the transfer of management accounting methods and tools by multinational corporations and foreign companies to subsidiaries operating in Poland and Romania. This mechanism is also related to the harmonization of accounting and financial reporting rules, imposed in the two countries by their EU membership. Professionalization, academic education and vocational training (normative isomorphism) are further factors contributing to the similar use of management accounting information in companies operating in Poland and Romania. This applies both to companies with local capital and to foreign ones. The influence of advisory firms and copying practices (mimetic isomorphism) is another factor, which strongly influences the shape of management accounting information in companies operating in such young market economies. Management accounting methods used in companies operating in the researched countries are therefore copied from the models in developed countries.

Our paper contributes to a better understanding of the management accounting use in Poland and Romania. This comparison between two CEE countries fills the existing gap in the comparative studies of management accounting and is useful for management accounting theory, as well as for corporate practices of companies operating in the Central and Eastern Europe (sees Endenich et al., 2011). It confirms the findings on the impact of isomorphism on similarities in the design and use of management accounting systems (see Granlund and Lukka, 1998; Granlund, 2001).
As to the limits of the research, we should point to the small number of responses we relied on, which doesn't allow us to universalize our conclusions. Moreover, the use of questionnaire-based surveys is generally not sufficient in thoroughly assessing the opinions of the managers. A second research stage, consisting in interviews of the questioned managers, would have supported the authors in drawing a complete picture of the use of management accounting.

\section{REFERENCES}

Ahrens, T. (1996). Styles of Accountability. Accounting, Organizations and Society, 21(2/3), 139-73.

Albu, C. N., \& Albu, N. (2012). Factors Associated with the Adoption and Use of Management Accounting Techniques in Developing Countries: The Case of Romania. Journal of International Financial Management \& Accounting, 23(3), 50-69.

Chow, C. W., Kato, Y., \& Merchant, K. A. (1996). The Use of Organizational Controls and their Effects on Data Manipulation and Management Myopia: A Japan vs. US Comparison. Accounting Organizations and Society, 21(2/3), 175-92.

DiMaggio, P. J., \& Powell, W. W. (1983). The Iron Cage Revisited: Institutional Isomorphism and Collective Rationality in Organisational Fields. American Sociological Review, 48, 147-160.

Endenich, C., Brandau, M., \& Hofjna, A. (2011). Two decades of research on comparative management accounting-achievements and future directions. Australian Accounting Review, 59(21/4), 365-382.

Granlund, M. (2001). Towards explaining stability in and around management accounting systems. Management Accounting Research, 12, 141166.

Ganlund, M., \& Lukka, K. (1998). It`s a Small World of Management Accounting Practices. Journal of Management Accounting Researches, 10, 153- 179 .

Grosu, C., Almasan, A., \& Circa, C. (2014). The current status of management accounting in Romania: the accountants' perspective. Journal of Accounting and Management Information Systems, 13(3), 537-558.

Meyer, J. W., \& Rowan, B. (1991). Institutionalized Organisations: Formal Structure as Myth and Ceremony. In W.W. Powell, P.J. DiMaggio (Eds.). The New Institutionalism in Organizational Analysis. The University of Chicago Press: Chicago. 
Shields, M. D., Chow, C. W., Kato, Y., \& Nakagawa, Y. (1991). Management Accounting Practices in the US and Japan: Comparative Survey Findings and Research Implications. Journal of International Financial Management and Accounting, 3(1), 61-77.

Szychta, A. (2002). The scope of application of management accounting methods in Polish enterprises. Management Accounting Research, 13(4), 401-418.

Wagenhofer, A. (2006). Management Accounting Research in German-Speaking Countries. Journal of Management Accounting Research, 18, 1-19.

\section{Appendix: The questionnaire survey}

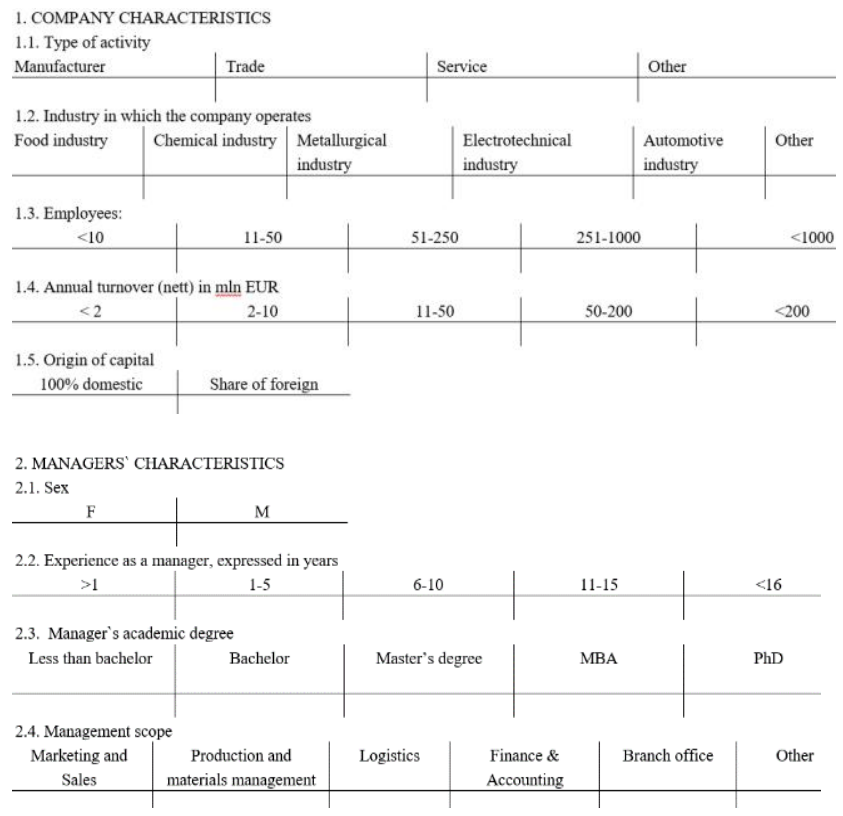

3. MANAGEMENT ACCOUNIING SYSTEM

3.1. Is the management accounting department in your company?

$$
\begin{array}{c|c}
\text { 3.1. Is the management accounting department in yo } \\
\text { YES } & \text { NO } \\
\hline
\end{array}
$$

4. MANAGER \& MANAGEMENT ACCOUNTING

\begin{tabular}{l|l|l|l|l|l} 
4.1. I use management accounting for: & 5- often & 3-oceasionally & 2-rarely & 1-never \\
\hline Long term planning & & & & & \\
\hline Implementing strategy & & & & & \\
\hline Preparing budgets & & & & & \\
\hline $\begin{array}{l}\text { Performance } \\
\text { measurement }\end{array}$ & & & & & \\
\hline $\begin{array}{l}\text { Increase profitability } \\
\text { Managing my } \\
\text { department }\end{array}$ & & & & & \\
\hline $\begin{array}{l}\text { Make or buy/ } \\
\text { outsourcing decision } \\
\text { making }\end{array}$ & & & & & \\
\hline Investment decision & & & & & \\
\hline R\&D decisions & & & & & \\
\hline Cost reduction & & & & & \\
\hline Cost control & & & & & \\
\hline $\begin{array}{l}\text { Assessing internal } \\
\text { projects }\end{array}$ & & & & & \\
Other purposes..... & & & & & \\
& & & & &
\end{tabular}

4.2. Please indicate importance of management accounting information for performing your managerial tasks?

\begin{tabular}{l|c|l|l|l|l} 
& $\begin{array}{c}5 \text { - very } \\
\text { important }\end{array}$ & 4- important & 3- neutral & 4 - unsuitable & $\begin{array}{c}5- \\
\text { completely } \\
\text { useless }\end{array}$ \\
\hline Costs & & & & & \\
\hline Revenues & & & & & \\
\hline Financial results & & & & & \\
\hline $\begin{array}{l}\text { Financial } \\
\text { indicators }\end{array}$ & & & & & \\
\hline $\begin{array}{l}\text { Variances analysis } \\
\text { Non-financial } \\
\text { indicators }\end{array}$ & & & & & \\
\hline $\begin{array}{l}\text { Actual financial } \\
\text { data }\end{array}$ & & & & & \\
\hline $\begin{array}{l}\text { Planned financial } \\
\text { data }\end{array}$ & & & & & \\
\hline Other......... & & & & & \\
\hline
\end{tabular}

